\title{
SELF-DETERMINATION: WHAT LESSONS FROM KASHMIR?
}

\author{
ISHITA CHAKRABARTY*
}

\begin{abstract}
This Article takes the example of Kashmir as a longstanding dispute, to illustrate the complexity that is self-determination. The Article shows that even massive human rights violations coupled with seizure of a sub-State group's right to autonomy may not be enough. The international community appears to be wary of taking a stand on a sub-State group's right to self-determination because of apprehensions that they may pass into norms, for it is in the interest of every state that their territorial integrity is not permanently altered through the exercise of external self-determination. The success of a sub-State group's legitimate claims has always been preceded either by coercive military (e.g., Kosovo, Bangladesh) or non-military interventions (e.g., East Timor). In invoking the Responsibility to Protect and the growing importance of the human rights framework, this Article attempts to show that the international community must reassess its stand.
\end{abstract}

* Ishita Chakrabarty received her BA LL.B (Hons.) from Hidayatullah National Law University. She is currently engaged in the role of Research Officer at Quill Foundation, New Delhi, India, where she works over matters related to citizenship, counter-terrorism and minority rights. Her area of interests include refugee laws and international humanitarian law. The Author wishes to thank Ariel Lynn Anderson and the entire editorial team at Indiana International and Comparative Law Review for their support. All errors are the Author's own. The Author can be contacted at: ishita.chakrabarty24@gmail.com. 


\author{
TABLE OF CONTENTS \\ INTRODUCTION \\ I. FrOM 1947 TO 2019: A HiSTORY OF THE KASHMIRI STRUGGLE \\ A. Kashmir as a Contested Territory between India and Pakistan \\ B. Kashmir as an Autonomous Unit within the Indian Constitution \\ II. THE RIGHT OF SELF-DETERMINATION \\ III. WHAT DOES THIS MEAN FOR KASHMIR? \\ IV. SELF-DETERMINATION: A HOLLOW 'RIGHT'? \\ CONCLUSION
}

\title{
INTRODUCTION
}

On August 5, 2019, the Indian government unilaterally, and in defiance of the constitutional procedures, revoked Article 370 of the Indian Constitution that guaranteed a "special" or autonomous status to the Indian Administered Kashmir (the "IAK") territory. ${ }^{1}$ This was followed by the enactment of the Jammu and Kashmir Reorganisation Act of 2019 (the "Act"), which extended the provisions of the Indian Constitution to the whole of the territory and divided the state into three parts, all of which are now to be federally controlled. ${ }^{2}$ Additionally, the

1. See generally Gautam Bhatia, The Article 370 Amendments: Key legal Issues, InDIAN Const. L. \& PHIL. (Aug. 5, 2019), https://indconlawphil.wordpress.com/2019/08/05/the-article-370amendments-key-legal-issues/ [https://perma.cc/2ZKQ-JE76] (discussing how the Federal Government introduced a Presidential Order (C.O. 272) to amend Article 370(1)(d) of the Indian Constitution through a convoluted procedure, in the absence of consent from the Legislative Assembly of the State. The elected government in the then State of Jammu and Kashmir fell due to differences within the electoral alliance in 2018. This resulted in the imposition of a 'President's rule' since 2018. During the imposition of a President's rule, the Governor (who is a nominated member and often considered as an agent of the Federal government) is left to administer the state while the elected assembly is suspended. Since the Centrally nominated agent is not representative of the electorate, major political decisions should not be affected by the Governor. Article 370 also recognizes that decisions over the future of the territory would be taken only by a "constituent assembly". However, the Central Government claimed that in the absence of an elected government, the power to revoke or modify the status of the State could be exercised by the President in consultation with the Governor of the State. This implies that the Centre essentially consulted itself in the matter of revocation).

2. InDIAn CONST. art. 370. Previously, the State of Jammu and Kashmir had its own Constitution and was only governed through the provisions under Article 1 and Article 370 of the Indian Constitution. This provision was explicitly included under Article 370(1)(c) of the Indian Constitution itself. Ministry of Law and Justice, The Constitution (Application to Jammu and Kashmir), Order, 2019, C.O. 272, clause 2 (Notified on Aug. 5, 2019) http://egazette. nic.in/WriteReadData/2019/210049.pdf [https://perma.cc/N28Q-C4MX] (extending the Indian Constitution to the territory); The Jammu and Kashmir Reorganisation Act, 2019, http:// egazette.nic.in/WriteReadData/2019/210407.pdf [https://perma.cc/LYX5-XT8U] (allowing for the 
Federal Government passed the Adaptation Order of 2020, extending domiciliary status to Indian citizens who have resided or worked in the territory for a certain time period, including bureaucrats, children of bureaucrats, migrant laborers, and army officers. ${ }^{3}$ Before the passing of the Act, the power to define residents lay with the state government and outsiders were not eligible for buying immovable property or seeking jobs within the state. ${ }^{4}$

Further, the government went on to arbitrarily detain all political leaders, impose blanket restrictions on movement, and a communications blackout, arguing that these were necessary counter-terrorism and security measures. ${ }^{5}$ The international community's response was lukewarm, at best. Pakistan responded by imposing diplomatic and trade sanctions over India, threatening to move the International Court of Justice (the "ICJ") over human rights violations in IAK. ${ }^{6}$ China decided to support Pakistan by convening a closed-door United Nations Security Council (UNSC) meeting to discuss the Kashmir issue. However, the resolution created in that meeting was vetoed by India's allies, Russia and France, citing the 1972 Simla Agreement that provides for a "bilateral settlement" of the issue. ${ }^{7}$ The United States has washed its hands of the state of affairs by only

bifurcation of the territory into two parts, comprising of Union Territories, which, as opposed to States, are administered by Governors directly appointed by the Central Government, and hence have reduced autonomy).

3. Baba Tamim, Kashmiris Equate India's New Domicile Law with Israel's 'SettlerColonial' Project, MidDLE EAST EyE (Apr. 1, 2020), https://www.middleeasteye.net/news/indiaskashmir-domicile-order-equated-settler-colonial-project [https://perma.cc/3Y8S-JY8Y].

4. Indian CONST. art. 35A (now revoked). Art. 35A does not follow Article 35 and is instead inserted within Appendix I to the Constitution. Appendix I, The Constitution (Application to Jammu and Kashmir), Order, 1954, C.O. 48, § 4(j) (issued on May 14, 1954), https://www.india.gov.in/sites/upload_files/npi/files/coi_appendix.pdf [https://perma.cc/KSH442UR].

5. India: Basic Freedoms at Risk in Kashmir, HRW (Aug. 6, 2019, 10:25 PM), https:// www.hrw.org/news/2019/08/06/india-basic-freedoms-risk-kashmir [https://perma.cc/V8YU-DG3F] (noting that over 4,000 political leaders and those with political affiliations have been detained, and many of them have been shifted to far-away jails, depriving contacts with families and impeding legal access).

6. See Priya Pillai, Pakistan v India at the International Court of Justice on Kashmir, OPINIO JURIS (Aug. 25, 2019), http://opiniojuris.org/2019/08/25/pakistan-v-india-at-theinternational-court-of-justice-on-kashmir/ [https://perma.cc/K733-8BS3]. Pillai discusses that since neither of the Parties have agreed to the compulsory jurisdiction of the ICJ under Article 36(2) of the ICJ Statute (India had submitted a Declaration in 1974 explicitly ruling out disputes between a former or present member of the Commonwealth Nations), it is unlikely that the Court would have something to say over the matter, although Pakistan could approach the Court citing violation of a particular Treaty that provides for dispute resolution by the ICJ. Id.; see also Parvez Hassan, Kashmir \& the ICJ, DAwn (Sept. 2, 2019), https://www.dawn.com/news/1503071 [https://perma. cc/PH5W-ZZN6].

7. See Simla Agreement, infra note 25. The UNSC took up the Kashmir issue for the first 
offering to "mediate," while the members of the Organization of Islamic Council (the "OIC") - a regional organization proclaiming to protect "Islamic interests" - have hardly responded to the issue. ${ }^{8}$ This was surprising, considering that in 1994 the OIC intended to submit a resolution condemning India's human rights violations in Kashmir before the UN Human Rights Commission (UNHRC). ${ }^{9}$ The OIC had planned to further refer the resolution to the UNSC to impose economic sanctions and other coercive measures against India. ${ }^{10}$ Moreover, the OIC Member States' position also appears to be in contrast to their position over the Citizenship Act, where they expressed concerns over the protections guaranteed to the Muslim minority in India. ${ }^{11}$ In the former instance, the United Nations High Commissioner for Refugees (the "UNHCR") has also sought permission to intervene before the Apex Court. ${ }^{12}$

Why have different standards been adopted by the international community over the treatment meted out to the "minorities" and the rights of the "peoples" over the Muslim majority territory of Kashmir? Why do self-determination struggles succeed in some cases, and fail in others?

While the issue of the revocation's validity under municipal law has been the subject of constant deliberation, its international repercussions have hardly been explored. Taking a traditionalist view of sovereignty, most responses have largely refrained from addressing the self-determination rights of Kashmiris and have

time since 1965. For a comprehensive status over the international community's response, see Global Conflict Tracker, COUNCIL ON FOREIGN REL., https://www.cfr.org/interactive/globalconflict-tracker/conflict/conflict-between-india-and-pakistan (last updated Apr. 20, 2020) [https:// perma.cc/4P9J-9TSD].

8. India has also received support from the UAE, Bahrain, Afghanistan, and Saudi Arabia. In fact, Saudi Arabia went ahead to sign one of the biggest investment deals with Reliance Industries during the same time. Meanwhile, Kuwait, Oman and Qatar have refrained from making any public statements. Turkey too has had a somewhat mellowed response, calling for promotion of dialogue between the two countries, rather than coercion. Giorgio Cafiero, India's Actions in Kashmir and the Muted response from the Arab Gulf States, TRT WORLD (Aug. 23, 2019), https:/www.trtworld.com/opinion/india-s-actions-in-kashmir-and-the-muted-response-from-arabgulf-states-29233 [https://perma.cc/8XT7-67JY].

9. Iftikhar Gilani, Opinion - Saudis Follow Iran's 1994 Somersault on Kashmir at OIC, ANADOLU AGENCY (Feb. 11, 2020), https://www.aa.com.tr/en/analysis/opinion-saudis-follow-irans-1994-somersault-on-kashmir-at-oic/1730770 [https://perma.cc/S3Y6-CUDX].

10. Teesta Setalvad, Understanding Article 370, Citizens for Just. \& PeACE (Aug. 5, 2019), https://cjp.org.in/article-370-and-the-hindu-right/ [https://perma.cc/7ZU9-N4XC].

11. OIC Expresses Concern over CA: Says 'Closely' Following Developments, ECON. TIMES (Dec. 23, 2019), https://economictimes.indiatimes.com/news/politics-and-nation/oic-expressesconcern-over-caa-says-closely-following-developments/articleshow $/ 72931689 . \mathrm{cms}$ ?from=mdr [https://perma.cc/EZA2-JXDH].

12. Samanwaya Rautray \& Dipanjan Roy Chaudhury, UNHCR Moves Supreme Court Against CAA: India Rejects Intervention, ECON. Times (Mar. 4, 2020), https://economictimes. indiatimes.com/news/politics-and-nation/unhcr-moves-sc-against-caa-india-rejectsintervention/articleshow/74468523.cms [https://perma.cc/V6DT-BSSJ]. 
solely referred to the issue of human rights violations. Academicians, with the notable exceptions of a few, continue to refer to and analyze the contested territory as a "state" within the "union of states" that is India, ${ }^{13}$ without situating the annexation of the territory in its particular historical context. To this end, this Article will begin by reflecting on the 1947 annexation leading up to the current situation. In Section II, this Article will deal with the international jurisprudence on self-determination to show the materialization of such a right. In the final section, taking a cue from the Kashmir example, this Article will discuss the hollowness of such a right in the absence of the international community's participation.

\section{FROM 1947 TO 2019: A HISTORY OF THE KASHMIRI STRUGGLE}

\section{A. Kashmir as a Contested Territory between India and Pakistan}

On the eve of Independence, there were two categories of territories in India: (1) those under the direct control of the British administration, and (2) princely states, approximately 565, governed indirectly by rulers through subsidiary alliance treaties with the colonial administration. In the latter case, the Maharajas and Nizams retained their de jure positions, but powers over defense, communications, and external affairs remained with the colonial administrators. These territories were given an option to join either of the two dominions (India or Pakistan) or remain independent. ${ }^{14}$ Most of the territories joined one of the two dominions on the basis of religion or geographical proximity.

Kashmir, however, faced a conundrum: the ruler Hari Singh was a Hindu while his subjects were primarily Muslims, who were held under an oppressive regime. ${ }^{15}$ In fact, records would show that Kashmir's struggle for freedom from occupation preceded the Indian accession. ${ }^{16}$ Hari Singh's procrastination in

13. See M.L. Sharma v. Union of India, W.P. (C) 1013/2019 (Supreme Court Observer) (contending that the government cannot seek to do that indirectly which it cannot perform directly ("doctrine of colourability"). The petition also challenged the constitutionality of the Reorganisation Act that effectively downgrades the relation between the Federal Government and the territory to that of a Union Territory and hence, takes away its rightful exercise of autonomy).

14. Faizan Mustafa, Article 370, Federalism and the Basic Structure of the Constitution, THE INDIA FORUM (Sept. 27, 2019), https://www.theindiaforum.in/article/article-370-federalism-andbasic-structure-constitution [https://perma.cc/58GW-NMGU].

15. Jyoti BHushan Das Gupta, JAMmu AND KashmiR 22-23, $30-32$ (1968), https://doi.org/10.1007/978-94-011-9231-6; March 16, 1846: A Nation Sold, GrEATER KASHMIR (Mar. 14, 2014), https://www.greaterkashmir.com/news/opinion/march-16-1846-a-nation-sold/ [https://perma.cc/4BFB-D52J] (discussing how Kashmir was sold to the Dogra ruler, Gulab Singh by the British Administration under the Treaty of Amritsar in 1846. The Dogras were known to have enacted laws taxing their Muslim subjects on the basis of their religion and denying them freedom to openly practice Islam).

16. See Abhinav Chandrachud, The Abrogation of Article 370, in EssAYs AND 
acceding to either of the territories by the deadline implied that Kashmir was "technically independent." 17 It was not until an oncoming invasion from the northwestern tribes that Hari Singh decided to finally accede to India in exchange for military assistance. This act was contested by Pakistan as an illegal, nonbinding action, eventually leading to war between the two countries. ${ }^{18}$

The Security Council Resolution 47 of 1948, adopted after representation from both the governments, noted that the continuance of the conflict posed a threat to "international peace and security" and that both the countries were in favor of holding a plebiscite within the territory. ${ }^{19}$ Towards this, Pakistan was under an obligation to withdraw its own troops from the contested region and withdraw any form of material aid towards the invaders; on the other side, India was under an obligation to reduce the military presence to a number just enough to maintain law and order. The plebiscite, additionally, was to take place under conditions respectful of the choices of the minorities. ${ }^{20}$ Kashmir was partitioned along a cease-fire line that eventually came to be known as the Line of Control (the "LOC"). ${ }^{21}$

For political reasons, the question of holding a plebiscite lost traction by the 1950s. Jammu and Kashmir presented a unique problem: the territory saw three parallel administrations involving Azad Kashmir and the remote northern areas led by a Pakistan-appointed authority (on the Pakistan side) and the IAK. ${ }^{22}$ This rendered a plebiscite physically and administratively difficult and neither side was agreeable to holding a plebiscite solely in the Kashmir valley and the "uncertain areas around Muzaffarabad." 23

Reminiscences: A Festschrift in Honour of Nani Palkhivala (Arvind Datar ed., 2020), https://papers.ssrn.com/sol3/papers.cfm?abstract_id=3448331 [https://perma.cc/6AF8-6AQ2] (describing how Sheikh Abdullah, the leader of the Jammu and Kashmir National Conference was arrested on the ground that he had been leading the 'Quit Kashmir' movement, demanding for the abrogation of the Treaty of Amritsar).

17. See Alastair Lamb, Kashmir: A Disputed Legacy 1846-1990 154 (1991).

18. Ŝmit Ganguly, The Crisis in Kashmir: Portents of War, Hopes of Peace 10 (The Woodrow Wilson Center Press 1997).

19. S.C. Res. 47, at 4 (Apr. 21, 1948), https://unmogip.unmissions.org/security-councilresolution-47-1948 [https://perma.cc/9FAW-ZAMY] ("considering that the continuation of the dispute is likely to endanger peace and security").

20. Id.

21. The cease-fire was agreed upon by the military representatives of both the countries in the presence of the UN Truce Committee (UN Commission for India and Pakistan) in 1949. The Line of Control divided IAK from the Pakistan Administered Kashmir (PAK) territories of Azad Kashmir and the North Areas of Gilgit-Baltistan. The Agreement also allowed for the presence of the UN Observers in both the territories. COMM'N FOR INDIA \& PAK., Agreement between Military Representatives of India and Pakistan regarding the establishment of a cease-fire line in the state of Jammu and Kashmir S/AC.12/TC.4 (1949).

22. Josef Korbel, The Kashmir Dispute After Six Years, 7(4) InT'L ORGS. 498-510 (1953).

23. See Christopher Snedden, Would a Plebiscite Have Resolved the Kashmir Dispute?, 28 J. S. ASIAN STUd. 75 (2005). 

FROM KASHMIR?

In 1971, India, yet again, entered into war with Pakistan over Bangladesh's (earlier East Pakistan) calls for self-determination that resulted in a large influx of refugees from the neighboring State, who were escaping the Pakistani army-led massacre. ${ }^{24}$ India did manage to recapture some of the territory in the Kashmir region during this war, which was finally settled with the signing of the 1972 Simla Agreement. ${ }^{25}$ The Simla Agreement provided that any dispute between the countries would be solved only through "bilateral" or other means agreed upon. Hence, in the Kashmir dispute, India contends, and the UN Secretary General also agrees, that the Simla Agreement has turned the dispute into an "internal matter", by putting an end to the plebiscite question. ${ }^{26}$ Nevertheless, the same agreement also mentions that neither country could change the status of the contested territory unilaterally.

\section{B. Kashmir as an Autonomous Unit within the Indian Constitution}

Shrimoyee Ghosh notes how Article 370 of the Indian Constitution was subsequently drafted and placed in the Indian Constitution under Part 21, dealing with temporary, special, and transitional provisions for certain states within the Union. ${ }^{27}$ Provisions under this part of the Constitution allow for a degree of selfgovernance, autonomy, and collective rights over land to the exclusion of other citizens of the Union. ${ }^{28}$ Ghosh then goes further to show how the terms of incorporation of the provision itself were erroneous. ${ }^{29}$ Unlike the other princely states, as per the Delhi Agreement of 1952 negotiated between Hari Singh and the Indian Government, the ruler only sought to give away his law-making powers temporarily to allow the people to decide the subject of accession for themselves

24. Anne Noronha Dos Santos, Military Intervention and Secession in South Asia: the CASES of Bangladesh, SRi Lanka, Kashmir ANd Punjab 23-41 (2007).

25. See Agreement on Bilateral Relations between the Government of India and the Government of Pakistan, India-Pak., July 2, 1972, 858 U.N.T.S. 71 [hereinafter Simla Agreement].

26. See Shirmoyee Ghosh, Chief Rejects Pak's Mediation Request, Cites Simla Agreement that says Kashmir a Bilateral Issue, ECON. TimES (Aug. 9, 2019), https://economictimes.indiatimes. com/news/politics-and-nation/un-chief-rejects-paks-mediation-request-cites-simla-agreement-thatsays-kashmir-a-bilateral-issue/articleshow/70600296.cms?from $=\mathrm{mdr} \quad[\mathrm{https}: / /$ perma.cc/2UJY8WNQ].

27. Shrimoyee Nandini Ghosh, Dismantling Kashmir's Special Status, One Nation, One Flag, One Constitution?, RAOIT Challenging The Consensus (Sept. 16, 2019), http://www.raiot.in/ dismantling-370-in-kashmir-part-1/ [https://perma.cc/8ZB5-KZZN].

28. InDIA CONST. Part XXI, https://www.mea.gov.in/Images/pdf1/Part21.pdf [https://perma. cc/H8VQ-HZLP]. (This part includes provisions for several states such as then Jammu and Kashmir (now revoked), Nagaland, Assam, Manipur, Mizoram, Sikkim, etc. that relate to autonomy and selfgovernance, retention of customary practices, religious freedoms, power to define who should own the state, representation of tribals in legislative assemblies, non-interference of any Central bodies in respect of any treaties that the state might have entered into prior to annexation, etc.).

29. Ghosh, supra note 26. 
once normalcy was restored. ${ }^{30}$ Until such time, a constituent assembly would be set up for the state to determine its relationship to the Union and adoption of a state constitution. Although the terms of the Article mirrored those of the Accession instrument, it failed to underline the surrounding context such as the disputed status of the whole territory, India's role in taking the dispute before the UN Security Council, and the United Nation's advice on holding of a plebiscite in the whole territory. Ghosh concludes that therefore the territory never truly intended to merge with the Indian Union. ${ }^{31}$ However, the State Constitution adopted in 1956 mentions otherwise. Article 3 of the State Constitution refers to the territory as an "integral part thereof," although Article 370 remained on the books. $^{32}$

Several academicians document how over the years Article 370 has been diluted by the federal government and the Apex Court in an attempt to forcibly integrate the territory within the Union, including by the continuous imposition of the President's rule and legislating upon matters exclusively within the state list. $^{33}$

30. The Delhi Agreement, 1952 (Aug. 28, 1973) (India), https://www.satp.org/ satporgtp/countries/india/states/jandk/documents/papers/delhi_agreement_1952.htm [https://perma.cc/XR5C-BWT8].

31. Ghosh, supra note 26.

32. Jammu And Kashmir Const., Nov. 17, 1956, pt. 2 art. 4. The Constituent Assembly for the State was dissolved in 1957 after the enactment of the State's Constitution. However, the adoption of this Constitution itself has been contested in several quarters. The 1951 Constituent Assembly has been held as not representative of the interests of all Kashmiris. See id.; LAMB, supra note 17, at 286-87; see generally MIR QASIM, MY LIFE AND TIMES (1992) (describing how all elections between 1951 and 1987 have been rigged through methods such as ghost voters, intimidation of voters into lowering turnouts. The 1987 rigging was a major factor in the anti-Indian uprising in 1989). See also Letter from Sheikh Mohd, Abdullah to Prime Minister Indira Gandhi (Nov. 2, 1975), in Abdul Jabbar Ganai, Kashmir and National Conference and Politics (1975-1980) 162-63 (1984) (describing how Sheikh Abdullah signed the Kashmir Accord with then Prime Minister Indira Gandhi, agreeing that Kashmir's accession to India was complete, in return of his ascendancy to power).

33. Article $35 \mathrm{~A}$ was incorporated through a presidential order in 1954 , which sought to incorporate the terms of the 1952 agreement but far exceeded its scope, allowing for the extensions of citizenship provisions, supreme court jurisdiction, and the constitution's chapter on Fundamental Rights. Forthcoming work discusses how the Apex Court from the late 1950s onwards has held that the powers of the Executive acting through the President under Article 370 were wide and could fundamentally change the State Constitution. The State has consistently used these overbroad powers to change how the laws of preventive detention operate in the state for instance, to the exclusion of the rest of the Union. The Apex Court also held in one instance that the state of Jammu and Kashmir could have no "vestige of sovereignty outside India." See, e.g., Chandrachud, supra note 16 , at $17-20$. 


\section{THE RIGHT OF SELF-DETERMINATION}

Traditionally, territories were divided on an arbitrary basis. Their evolution into modern states was preceded by realignments, primarily based on the people's ethnicities. ${ }^{34}$ This redrawing of boundaries inevitably involved selfdetermination, ${ }^{35}$ but the principle itself was incorporated much later through the adoption of the UN Charter Articles 1992 and 55. ${ }^{36}$ The insertion of these terms did not carry any legal obligations at the time. It was not until the adoption of the International Covenant on Civil and Political Rights (ICCPR) ${ }^{37}$ and the International Covenant on Economic, Social, and Cultural Rights (ICESCR) ${ }^{38}$ that there emerged a "right" of self-determination under treaty law. The two covenants were adopted subsequent to the 1960 Declaration on the Granting of Independence to Colonial Countries and Peoples. ${ }^{39}$ Perhaps this is why the scope of this right under the covenants was limited to "colonized" peoples including "trusts and non-self-governing territories." ${ }^{40}$ This right was similarly reiterated under The Declaration on Principles of International Law Concerning Friendly Relations and Co-operation among States in Accordance with the Charter of the United Nations (the 1970 Declaration) adopted by the UN General Assembly. ${ }^{41}$ The 1970 Declaration was the result of state consensus that clarified that existing

34. Daniel Patrick Moynihan, Pandaemonium:Ethnicity in InTERnational Politics 3-5 (1993).

35. See Milena Sterio, The Right to Self Determination under International Law: Selfistans, Secessions And the Rule of the Great Powers 10 (2013) (describing the breakup of Austro-Hungary on the basis of ethnicity. The Principle remained only as a 'guiding factor' during the Paris Peace Conference. Woodrow Wilson's proposal to include any reference to selfdetermination in the League of Nations Charter was also voted down).

36. U.N. Charter states, "To develop friendly relations among nations based on respect for the principle of equal rights and self-determination of peoples." Art. 1 - 2 . "With a view to the creation of conditions of stability and well-being which are necessary for peaceful and friendly relations among nations based on respect for the principle of equal rights and self-determination of peoples, the United Nations shall promote." Id. at art. 55.

37. International Covenant on Civil and Political Rights art. 1, opened for signature on Dec. 16, 1996, 999 U.N.T.S. 171.

38. International Covenant on Economic, Social and Cultural Rights art. 1, opened for signature on Dec. 16, 1966, 993 U.N.T.S. 3.

39. G.A. Res. 1514 (XV) (Dec. 14, 1960).

40. Article 1 of the ICCPR and ICESCR reads: "All peoples have the right to selfdetermination . . . The State Parties to the present Covenant, including those having responsibility for the administration of Non-Self-Governing and Trust Territories, shall promote the realization of the right of self-determination, and shall respect that right, in conformity with the provisions of the Charter of the United Nations," G.A. Res. 2200A (XXI), art. 1 (Dec. 16, 1966); see also antonio Cassese, Self-Determination of Peoples: A Legal Reappraisal 52-62 (1995).

41. G.A. Res. 2625 (Oct. 24, 1970). 
territories should not be altered, ${ }^{42}$ except where they involved colonized territories. ${ }^{43}$

The 1970 Declaration also affirms the principle of territorial integrity, confirming that sub-States within decolonized or wholly constituted sovereign States did not enjoy such a right. However, the proviso does give the impression that under exceptional situations where the government fails to represent a territorial population marked by their race, creed, color, language, nationality, or culture, this general principle could be deviated from. ${ }^{44}$

Self-determination rights are said to vest within the "peoples." However, there is considerable doubt as to who these "peoples" are. At a minimum, it is clear that minorities are not entitled to self-determination and can only seek protection and rights on a non-discriminatory basis within the existing territory. ${ }^{45}$ To see whether such a sub-State group could comprise "peoples," international law requires an objective analysis on whether the group bears such a differentiated identity (marked by race, color, creed, language, nationality, or culture) within a territory and a subjective analysis of what the individual members perceive of their own collective identity. ${ }^{46}$ In certain cases, it is entirely

42. Rep. of the S.C., at 98-100, U.N. Doc. A/8018 (1970) [hereinafter Rep. of the S.C. on Principles of International Law] (discussing how, for instance, Poland emphasized "state frontiers" and the Canadian delegation believed that a broadly framed right of self-determination would jeopardize the rights of the others living in a multi-ethnic territory).

43. Rep. of the S.C., at 30-31, 43, U.N. Doc. A/7619 (1969). During the course of the session, several countries were in favor of explicitly enunciating the rights of independence to colonial peoples while balancing the rights of states to sovereignty and territorial integrity. For instance, one proposal wanted to include that states that seek decolonization are lawfully entitled to interventions in favor of their struggle, while another sought to outlaw any interventions in favor of a regime that colonized people who were entitled to self-determination.

44. See $i d$. at 121 (the reference to language, nationality, and culture was added subsequently); see also World Conference on Human Rights, Vienna Declaration and Program of Action, pt. 1, I 2, U.N. Doc. A/CONF.157/24 (June 25, 1993); G.A. Res. 50/6, U.N. Doc. A/RES/50/6 (Nov. 9, 1995).

45. See Conference on Yugoslavia Arbitration, Opinion on Questions Arising from the Dissolution of Yugoslavia: Commission Opinion No. 2, 1497, Jan. 11, 1992, 31 I.L.M. 1488. In the context of the Serbian minority in the states that had seceded from the parent state of Yugoslavia and wished to rejoin Serbia as a part of Federal Republic of Yugoslavia (FRY), the Badinter Commission reflected the stance of the European Community, stating that the Serbs in the newly created states would be entitled to all those rights that were accorded to minorities, and would additionally have the right to choose their respective nationalities. This, however, does not align with the traditional understanding of how secessions work. See STERIO, supra note 35, at 34-36 (noting that if the Commission had already identified the Serbian community in Bosnia and Croatia as "minorities," it should not have delved into the question of self-determination in the first place, and any observations over nationalities and the holding of passports while continuing to be a part of their respective territories is also an anomaly — rather it could have guaranteed cultural and social rights that are generally accorded to minorities under international law).

46. M.P. Scharf, Earned Sovereignty: Judicial Underpinnings, 31 DenV. J. INT'L L. \& PoL'Y 
possible that the existence of the territory consisting of such a collective preceded the existence of a parent State, in which case the objective criteria to evaluate the "peoples" is fulfilled. ${ }^{47}$ Castellino observes that this act of precedence itself could evolve from (1) the historical existence of a nation within another nation; or (2) the indigenous populations whose territory has been occupied by settlers from outside and who have been subjected to the role of "quasi-colonial subjects" within their own land.$^{48}$ For example, the latter case could refer to territories that have been invaded, annexed, or taken away through "subterfuge" to convert them into non-sovereign entities. ${ }^{49}$

Although, self-determination rights vest within the "people," the case of external self-determination (or "secession" involving separation from the parent State) is less obvious, apart from the case of those comprising a colonized population. Castellino believes that since indigenous populations were illegally deprived of their territories, they should be entitled to the same rights of selfdetermination as those available to colonized populations. ${ }^{50}$ Conversely, Scharf proposes an alternative test: whether such a group in a decolonized territory is collectively denied its civil and political rights and subjected to what he calls "egregious abuses," such as a systematic form of discrimination or illegal consolidation of territory. ${ }^{51}$ Scharf's test is consistent with certain decisions rendered in the Aaland Islands and Quebec disputes.

The Aalanders' argued to separate from Finland and join Sweden because the island population was ethnically Swedish. The Commission of Rapporteurs first concluded that the issue was properly of an international and not domestic nature. ${ }^{52}$ Further, the Commission concluded that there was no general right of self-determination; instead, minorities and groups constituting people had a right

373, 373-379 (2003).

47. See Sterio, supra note 35 , at 16 (discussing the examples of the indigenous groups of Brazil, Australia, or Canada).

48. Joshua Castellino, International Law and Self-Determination, in SELF DeterminATION AND SECESSION IN InteRnAtional LAW 27, 32-33 (Christian Walter, Antje Von Ungern-Sternberg \& Kavus Abushov eds., 2014) (arguing that the claims of Kashmiris may not gain a similar amount of consensus as those of Palestinians or Kurds).

49. Id. at 34 .

50. See Castellino, supra note 48 at 27 (citing art. 1 - 9 2-3 of the ICCPR and ICESCR and finding that there exists a legal obligation to not deprive "peoples" of their subsistence, which coexists with the provision that has been advocated for the decolonization of a population).

51. Scharf, supra note 46 , at 381.

52. Report of the International Committee of Jurists Entrusted by the Council of the League of Nations with the Task of Giving an Advisory Opinion on the Legal Aspects of the Aaland Islands Question, League of Nations O.J., Special Supp. No. 3, at 5-10 (1920) [hereinafter Advisory Opinion on the Legal Aspects of the Aaland Islands Question]; The Aaland Islands Question: Report Submitted to the Council of the League of Nations by the Commission of Rapporteurs, League of Nations Doc. B7/21/68/106 (1921) [hereinafter League of Nations Report on the Aaland Islands Question]. 
to autonomy within the existing or parent State. It was only when the parent State refused to ensure such autonomy, that the sub-State group could claim a right to separate as a "last resort" measure. ${ }^{53}$ In Canada, the Parliament referred the question of whether the Quebecois had a valid right to self-determination to the Supreme Court. The Court found that Quebecois were adequately represented within the territory and they could not claim such a right unless their autonomy was "totally frustrated internally." 54

At first, any materialization of a "right" to self-determination may seem odd and contrary to established principles of sovereignty and territorial integrity. ${ }^{55}$ However, subsequent decisions adjudicating conflicting claims on the right of self-determination led to the following conclusions. First, human rights violations serve as evidence to question the sovereignty of the state. In other words, absolute sovereignty does not exist. This understanding has been largely attributed to the growing human rights framework. ${ }^{56}$ Second, despite such violations, the principle of territorial integrity ensures that individuals or a collective must turn to states for redressal of these violations. ${ }^{57}$ In the context of self-determination, States must allow such sub-State groups to exercise their rights of autonomy and political participation within the existing structure (described as "internal selfdetermination"). ${ }^{58}$ Third, it is only when internal self-determination is denied that States can resort to their rights to external self-determination leading up to secession..$^{59}$

53. See League of Nations Report on the Aaland Islands Question, supra note 52. The Rapporteur observed that Finland should allow "just and effective guarantees" of minority rights including the protection of their cultural and ethnic autonomy. The Commission also observed that the breakup of Finland from its parent state Russia could not serve as a precedent since they had not been subjected to a similar "disloyal and brutal conduct." Id.

54. Reference re Secession of Quebec, [1998] 2 S.C.R. 217, ๆๆ 126-138.

55. See J.C. Dunoff, S.R. Ratner, \& D. Wippman, International Law: Norms, Actors, Processes 112 (3d ed. 2010) (defining secession and noting how rarely successful instances thereof have been).

56. See H. Steinberger, Sovereignty, in EnCyClopedia OF Public InTERnational Law 51516 (North-Holland Elsevier 2000).

57. See Advisory Opinion on the Legal Aspects of the Aaland Islands Question, supra note 52; League of Nations Report on the Aaland Islands Question, supra note 52.

58. See Advisory Opinion on the Legal Aspects of the Aaland Islands Question, supra note 52; League of Nations Report on the Aaland Islands Question, supra note 52.

59. See Katangese Peoples' Congress vs. Zaire, Communication 75/92, African Commission On Human and Peoples' Rights [African Comm'n H.P.R], I 6 (Mar. 22, 1995) (holding that since there was no concrete evidence that the people of Katanga had not been allowed to participate in the government under Article 13 \ 1 of the African Charter, they were only entitled to exercise a "variant of self-determination" that was compatible with the principles of territorial integrity of the state of Zaire). 

FROM KASHMIR?

\section{WHAT DOES THIS MEAN FOR KASHMIR?}

As we have observed throughout this Article, international law grants differing degrees of "rights" to colonized peoples, indigenous peoples, and peoples linked through bonds of nationhood. A colonized population has the right to external self-determination. However, the scope of rights of self-determination to indigenous peoples is less clear. Peoples who are linked through bonds of nationhood must additionally demonstrate their frustration of internal autonomy or exhaustion of internal self-determination along with large-scale human rights violations by the parent State. This is because unlike internal self-determination, external self-determination, which results in secession, disturbs the territorial integrity by altering the borders of an existing State. This is also why external self-determination rights are generally reserved for peoples who are still linked to the territory. ${ }^{60}$

Kashmir appears to meet all requirements that determine a "people." The Security Council Resolution of 1948 that favored a plebiscite could be said to rest upon this premise. In the first scenario of a nation state preceding the existence of a parent State, the Kashmir issue could be looked at through a decolonization or occupation lens. In Horowitz's views, once a colonized population has exercised its "rights" of self-determination, it expires - the population cannot claim a second chance at determining an alternative form of political governance. ${ }^{61}$ However, in the case of Kashmir, one could argue that the princely state could not have effectively exercised this right while under military coercion arising from the indirect colonial administration, and so such right has not been exhausted. ${ }^{62}$

Negotiations and resolutions have only treated Kashmiris as the object rather than the subject of law. This is the position several commentators have taken while arguing that Kashmir merely passed on from one colonizer to another. ${ }^{63}$ In

60. Castellino, supra note 46, at 27, 28-44.

61. D.L. Horowitz, A Right to Secede?, in SeCESSION AND Self-Determination 60 (Stephen Macedo \& Allen Buchanan eds., 2003).

62. See Tariq Ahmed, FALQs: Article 370 and the removal of Jammu and Kashmir's Special Status, L. LiBR. ConG.: FA (Oct. 3, 2019), https://blogs.loc.gov/law/2019/10/falqs-article-370-andthe-removal-of-jammu-and-kashmirs-special-status/ [https:/perma.cc/KW6K-ETJC] (discussing how existence as independent states was an option only 'theoretically' since the British forces offered effectively no military assistance. The princely states would have to join either of the two dominions); see CASSESE, supra note 40 at 260-63 (discussing how the breakup of the Baltic States from the Soviet Nation happened on the basis of their illegal annexation by the Soviet Union in 1940 and the invalidity of the Molotov Ribbentrop pact with Hitler in 1939. The Baltic States argued that the Union had incurred international responsibility over their annexation and hence did not possess a claim over the territory).

63. E.g., Mirza Waheed, India's Illegal Power Grab is Turning Kashmir into a Colony, THE GUARDIAN (Aug. 14, 2019), https://www.theguardian.com/commentisfree/2019/aug/14/narendramodi-kashmir-hindu-first-india-autonomy [https://perma.cc/E5DN-8A9J]. 
fact, East Timor and Chagos Islands have seen similar conclusions. East Timor was previously a Portuguese colony that was forcibly annexed by Indonesia after the withdrawal of the Portuguese in $1976 .{ }^{64}$ Although the ICJ did not rule over the State responsibility of Indonesia, as the country had not consented to the contentious jurisdiction of the court, the court nevertheless, stated that East Timor had a status of a non-self-governing territory and the peoples had a 'right' to selfdetermination. ${ }^{65}$ Whereas, in the Chagos Island dispute, the ICJ's Advisory Opinion clearly showed that a subordinate administration, in this case, Mauritius, could not have validly consented to the United Kingdom's takeover of Chagos; hence, the decolonization of Chagos Island was not complete. ${ }^{66}$

Alternatively, Indian scholar Faizan Mustafa proceeds on an international law principle of treaty compliance and the assumption that the territory existed as a nation preceding the Union of India. ${ }^{67}$ Mustafa notes that, with the final act of revoking what was left of Kashmir's autonomous status, India has breached the principle of pacta sunt servanda, effectively returning the territory to its preaccession position as a sovereign State. ${ }^{68}$ In any event, even if one were to view Kashmir as a state within the Union of India, the act of revoking its autonomous status could revive its claim to self-determination. To clarify, the matter is not an "internal matter," as is the UN Secretary General's, India's, and India's allies' position. The Aaland Islands' dispute leads to the conclusion that a call for external self-determination is an international matter ${ }^{69}$ As for Kashmir, two legal positions could arise: either the restoration of the situation ex-ante, which implies the restoration of statehood along with a separate status as under Article 370; or a more radical view of allowing a plebiscite.

It appears from the jurisprudence discussed above that the second view is correct. Once Kashmir's autonomous status has been revoked and the right to limited autonomy within the existing frontiers extinguished, a legitimate right to claim external self-determination vests upon the people. It would seem only logical that once a State has lost its legitimacy to rule over its people, it cannot be revived. For instance, Serbia was believed to have lost its legitimacy to govern Kosovo owing to its human rights violations ${ }^{70}$ and the ICJ's Kosovo Advisory Opinion is believed to be reflective of this despite the fact that there had been a lapse of time between the commission of violence and the declaration of

64. East Timor (Port. v. Austl.), Judgement, 1995 I.C.J., 90 (June 30).

65. Id., 31 (concerning the responsibility of Australia in concluding a Treaty (Timor Gap) with Indonesia, which had a de facto control over East Timor, rather than Portugal, which was the Administering Power).

66. See Marko Milanovic, ICJ Delivers Chagos Advisory Opinion, UK Loses Badly, EuR. J. INT'L L. TALK (Feb. 25, 2019), https://www.ejiltalk.org/icj-delivers-chagos-advisory-opinion-ukloses-badly/ [https://perma.cc/B5X4-NM3X] (citing 172 of the Chagos judgment).

67. Mustafa, supra note 14.

68. Id.

69. See discussion supra Section II.A.

70. Richard Falk, The Kosovo Advisory Opinion: Conflict Resolution and Precedent, 105 AM. J. INT'L L. 50, 53 (2011). 

FROM KASHMIR?

independence. $^{71}$

This jurisprudence should be cross-referenced with India's own state practice of acknowledging the "will of the people." Prior to the establishment of a Union, a plebiscite had been carried out in the territories of Sylhet and North-Western Frontier Provinces (NWFP) to determine which of the two countries, the "people" wished to accede to. ${ }^{72}$ India's own opinion with respect to the rest of the princely states had been to allow a plebiscite for the "peoples" to choose their own political governance; therefore, the Muslim ruler of the Hindu majority state of Junagadh could not have rightly acceded to Pakistan. Eventually, a referendum had to be held in the State, which resoundingly favored accession to India. ${ }^{73}$ In a subsequent case involving similar facts of accession, the Apex Court held that primacy had to be given to the "will of the people" over the will of the rulers who were clearly in support of the accession. ${ }^{74}$ Post-independence, India initially seemed to have taken a contrary stand. During the adoption of the 1970 Declaration, India took the view that the right of self-determination did not vest in sovereign and independent states, since they would otherwise lead to "fragmentation, disintegration and dismemberment of member states." 75 But in the year 1971, India itself intervened in the Bangladeshi struggle for selfdetermination; although, it did not explicitly invoke the existence of such a right and was quick to justify the intervention as one motivated by self-defense and against the huge influx of refugees into its territory. ${ }^{76}$ In 1987, India again intervened in the Sri Lankan conflict when members of the Tamil Eelam struggled to secede from the parent State. ${ }^{77}$ India linked its assistance to the cause

71. Christian Walter, The Kosovo Advisory Opinion, in Self Determination and Secession in International Law 13, 18 (Christian Walter, Antje Von Ungern-Sternberg \& Kavus Abushov eds., 2014).

72. See Snedden, supra note 23.

73. See Chandrachud, supra note 16 at 6-7 (discussing the case of the princely state of Junagadh that was ruled by a Muslim ruler but had a Hindu majority population).

74. Balu Gopalakrishnan Nair, Article 370: Is it a Basic Feature of the Indian Constitution?, VerfBlog (Aug. 20, 2019), https:/verfassungsblog.de/article-370-is-it-a-basic-feature-of-theindian-constitution/ [https://perma.cc/4DLQ-NS78] (in R Ganpatrao v. Union of India the Apex Court held that accession would have nevertheless taken place but rejected the argument certain provisions in the constitution had attained the character of a "basic feature" that could not be abrogated by the Parliament under any circumstances because the identity of the Union itself would have been altered if they had not acceded to the dominion subject to certain agreements).

75. Rep. of the S.C. on Principles of International Law, supra note 42, at 110.

76. See Prime Minister Indira Gandhi's statement in the Indian Parliament on May 24, 1971, Ved P. Nanda, Self Determination in International Law: The Tragic Tale of Two Cities - Islamabad and Dacca, 66 Am. J. InT'L L. 321,334 n.94 (1972); Noronha Dos SANTOS, supra note 24, at 7, 38, 169 n.109 (referring to Swaran Singh's statement in the Lok Sabha on December 3, 1971).

77. India's intervention in the Sri Lankan War began in 1983, with the involvement of agencies like the Research and Analysis Wing (RAW) in training and provision of financial support. However, it was only around 1987 that the Indian government overtly intervened in the 
of the secessionists on grounds of ethnicity, mass killings, and repression and denial by the parent State to allow humanitarian aid. ${ }^{78}$

Both Bangladesh and Sri Lanka had similar demands limited to selfautonomy which escalated into calls for secession. ${ }^{79}$ The peoples' movements in both Bangladesh and Sri Lanka observed wide-spread violence and accounts of mass killings. Sri Lanka had seen its own offensive against minorities preceding the full-blown conflict, involving paramilitary presence to wipe out secessionists, enactment of counter-terrorism laws that conferred wide-ranging powers, leading to tortures and preventive detentions, communications blockade, and an economic embargo. ${ }^{80}$ While the Bangladesh war continued for just less than a year, the Sri Lankan Civil War started in 1983 and continued up till 2009. ${ }^{81}$ Although the Sri

context of an economic blockade imposed by the Sri Lankan government in the Tamil majority Northern Province, airdropping food and other reliefs. The same year, India sought to pressure the President to sign the India Lanka Accord to achieve a compromise with the Tamil ethnic minority, including through greater devolution of power. International Crisis Group, India and Sri Lanka After the LTTE, Asia Report No. 206, (June 23, 2011), https:/www.crisisgroup.org/asia/southasia/india-non-kashmir/india-and-sri-lanka-after-ltte [https://perma.cc/G342-5QJY].

78. The Indian Ambassador to Sri Lanka justified assistance to the secessionists, saying, "We had to respect the sentiments of the 50 million Tamil citizens of India. We felt that if we did not rise in support of the Tamil cause in Sri Lanka, we were not standing by our own Tamils." Noronha Dos Santos, supra note 24, at 63. The Indian High Commissioner in Sri Lanka stated his concerns over "all-out military assault as part of what has been described as a fight to finish. Thousands have already been killed in the ethnic conflict." Id. at 64 .

79. The Bangladesh conflict started with demands for linguistic rights and eventually led to full-scale protests involving civil and political liberties. Mujib-ur-Rehman proposed the 6-Point Program, which spoke of the existence of an autonomous unity within the federation in 1966, and the refusal to accede to popular demands by not allowing Mujib-ur-Rehman to participate in the Constituent Assembly although his party emerged as the largest party and he had the mandate of becoming the Prime Minister. The Sri Lankan Civil war started with the denial in 1958 to devolve power upon the Tamils and the enactment of discriminatory policies that favored those belonging to the other ethnicities, over the Tamil Eelam. See id. at 23-66.

80. The Bangladesh war began in March 1971 with an intention of terrorizing the population into submission. Within eight months of the conflict, the death toll over one million. In Sri Lanka, the situation erupted into a full-blown war in 1983 and involved "organized massacres" and large displacements. Within a week, there were reports of approximately 1,50,000 casualties and displacements. Subsequently, the government imposed an Operations Embargo in Jaffna. See id.

81. 1971 Liberation War, Birth of Bangladesh and Comparison with Present Day Pakistan, Publication Research Dossiers, Eur. Found. FOR S. Asian STUd., https://www.efsas.org/ publications/research-dossiers/1971-liberation-war,-birth-of-bangladesh-and-comparison-withpresent-day-pakistan/ [https://perma.cc/5KNF-83ZP] (last visited Feb. 14, 2020) (discussing how after the Indian army joined hands with the guerilla forces in capturing territories West Pakistani forces had to withdraw. This was followed by the signing of the surrender agreement by then General of Pakistan, on 16 December - after nine months of conflict); Jayshree Bajoria, The Sri Lankan Conflict, COUNCIL ON Foreign ReL. (May 18, 2009), https://www.cfr.org/backgrounder/ sri-lankan-conflict [https://perma.cc/FZH9-84FC] (the Sri Lankan government declared an end to 

FROM KASHMIR?

Lankan war did not result in secession, the two conflicts are indicative of India's opinion regarding the legitimacy of self-determination and in order to achieve them, intervention.

As for Kashmir, records are proof of how the state has engaged in vote riggings, interference in state affairs, detention of separatist leaders, and massive human rights violations, including through the imposition of collective punishments on the civilian population, ${ }^{82}$ resulting in what has been called a "legitimation crisis." ${ }^{13}$ While deciding whether a "peoples" must be afforded such self-determination rights, the question must not merely be of urgency but also inquire if the dispute has been long-standing. ${ }^{84}$ The overwhelming majority has stood for rights of external self-determination from India, for several decades now. The Office of the United Nations High Commissioner for Human Rights (the "OHCHR") has released two reports consecutively in 2018 and 2019 over the human rights situation in IAK and Pakistan Administered Kashmir (PAK). ${ }^{85}$ The

the war with the capture and killing of leader, Prabhakaran of LTTE, in 2009).

82. Ishita Chakrabarty, Calling Out Collective Punishments in the Context of the Kashmir Situation: Part I, GRO. J. INT'L L. BLOG (Jan. 21, 2019), https://grojil.org/2019/01/21/calling-outcollective-punishments-in-the-context-of-the-kashmir-situation-part-i/ [https://perma.cc/UGM7BNYU]; see also Ishita Chakrabarty, Calling Out Collective Punishments in the Context of the Kashmir Situation: Part II, GRO. J. INT'L L. Blog (Jan. 29, 2019), https://grojil.org/2019/01/ 29/calling-out-collective-punishments-in-the-context-of-the-kashmir-situation-part-ii/ [https://perma.cc/B874-T2YC] (discussing the Indian state's continuous occupation of Kashmir, repressive laws such as the Armed Forces Special Powers Act, imposed since 1990, the Public Safety Act, 1958, that have not seen a single prosecution since their application despite widespread accounts of torture, enforced disappearances, extrajudicial killings, presence of mass undocumented graves and the commission of war crimes in Kashmir).

83. See Javid Ahmad Ahanger, The New Mainstream and the Politics of Jammu and Kashmir, INVERSE J. (Feb. 18, 2020), https://www.inversejournal.com/2020/02/18/the-new-mainstream-andthe-politics-of-jammu-and-kashmir-by-javid-ahmad-ahanger/ [https://perma.cc/9JJU-ZN4W]; GANGULY, supra note 18, at 87.

84. Stefan Oeter, The Role of Recognition and Non-Recognition with Regard to Secession, in Self Determination and Secession in International Law 45, 60 (Christian Walter, Antje Von Ungern-Sternberg \& Kavus Abushov eds.,2014) (discussing the cases of Abhkhazia and South Ossetia, whose cases may not be equally deserving of external self-determination. Although these autonomous regions within Georgia felt initially threatened, they were promised military assistance by Russia. Hence, there did not seem to be a case of "extreme urgency").

85. See Office of the High Commissioner for Human Rights, Rep. on the Situation of Human Rights in Kashmir: Developments in the Indian State of Jammu and Kashmir from June 2016 to April 2018, and General Human Rights Concerns in Azad Jammu and Kashmir and Gilgit-Baltistan (June 18, 2018), https://www.ohchr.org/Documents/Countries/IN/DevelopmentsInKashmir June2016ToApril2018.pdf [https://perma.cc/K69B-PSMB]; Office of the High Commissioner for Human Rights, Update of the Situation of Human Rights in Indian-Administered Kashmir and Pakistan-Administered Kashmir from May 2018 to April 2019 (July 8, 2019), https://www.ohchr. org/Documents/Countries/IN/KashmirUpdateReport_8July2019.pdf [https://perma.cc/9U7C- 
UN Human Rights Chief even requested a Commission of Inquiry in $2019 .^{86}$ Moreover, the Adaptation Order of 2020 is in the nature of a "settler law" that would allow Indian citizens incursion within the territory, effectively changing the demographics of the state. ${ }^{87}$ The combined effect of the Order and Abrogation Act would be to effectively nullify the right to self-determination of the peoples. The ICJ in the Wall Advisory Opinion noted how the Security Council and General Assembly resolutions expressed similar concerns over Israel's construction of a wall in the occupied Palestinian Territory and the West Bank. ${ }^{88}$

Why then has the abrogation of Kashmir's autonomous status not evoked similar concerns over its right to external self-determination, from the international community?

\section{SELF-DETERMINATION: A HOLLOW “RIGHT”?}

British academician James Crawford stated in 1998 that state practice since 1945 did not extend a "right" to self-determination beyond those available to colonized peoples; hence, no unilateral right to secession existed. According to Crawford, any "right" to self-determination has to be exercised under the parent state's constitutional system and based on respect for its territorial integrity. ${ }^{89}$ Crawford believes that the cases of Bangladesh, Eritrea, and the Baltic States should not serve as an example of a right of secession, since these were achieved either through foreign military assistance or mutual consent; whereas, in cases where the States have opposed secessions such as South Ossetia or Abkhazia, secessionists have been unsuccessful. ${ }^{90}$

In saying so, Crawford appears to conflate two contexts: the existence of a right and the exercise of the right..$^{11}$ The discussion preceding this section would

DSKS].

86. Rifat Fareed, 'Breaking the Silence': Report Documents Torture in Kashmir, AL JAZEERA (May 20, 2019), https://www.aljazeera.com/news/2019/05/silence-report-documents-torturekashmir-190520060706202.html [https://perma.cc/HJ5Z-KCJE].

87. See Tamim, supra note 3 . Under the new rules, domicile certificates are being granted by the tehnsildar or an administrative official at the lowest level to expedite the process. By September 2020, approximately 12 lakh certificates had already been issued. Process of issuing domicile certificates Being Expedited In IIOJK, KASHMIR MEDIA SERV. (Sept. 20, 2020), https://kmsnews.org/news/2020/09/20/process-of-issuing-domicile-certificates-being-expedited-iniiojk/ [https://perma.cc/8BMG-HXL9].

88. Legal Consequences of the Construction of a Wall in the Occupied Palestinian Territory, Advisory Opinion, 2004 I.C.J. 136, ๆๆ 120, 134-135 (July 9), (noting that deportation or transfer of the civilian population of Israel into the occupied territory is a violation of Article 49 of the Geneva Convention IV).

89. James Crawford, State Practice and International Law in Relation to Secession, 1999 BRIT. Y.B. INT'L L. 114-16.

90. See id.

91. Nanda, supra note 76, at n.44. (discussing self-determination and secession or the exercise of such right of self-determination are not the same). 
show that international law has itself evolved to guide whether any calls for selfdetermination, internal or external, is legitimate; although, there are no rules yet on the exercise of such a right. Olga Shukovich proposes the other extreme, concluding that self-determination even under the UN Charter indicated a general principle of international law. ${ }^{92}$ Both Crawford and Shukovich seem to presume that a majority state practice is a necessary factor to assess the existence of a right to self-determination, although both come to different conclusions. ${ }^{93}$ However, realpolitik considerations would indicate that states would never consent to the establishment of such a right. ${ }^{94}$ Shukovich's conclusion is likely based on the premise that the right to self-determination, in the case of decolonization, is a principle of customary international law; ${ }^{95}$ however, the same conclusion cannot be juxtaposed in the case of non-colonized regimes. The paradox of a right to self-determination is that, although it is framed in terms of the rights granted to groups and communities, the realization of this right is left to the will of the States. Sarah Nouwen's work lends credence to this position. Nouwen finds that some states invoked the existence of self-determination rights well in advance of the $1960 \mathrm{~s}$ and 1970s when academicians began to discuss this right. Subsequently, however, the same states have been seen deviating from their own positions. ${ }^{96}$

92. Juan Francisco Escudero Espinosa, Self-Determination and Humanitarian SECESSION In INTERNATIONAL LAW OF A GLOBALIZED WorLD: KoSOVo V CRIMEA 14, n.40 (2017).

93. Crawford and Shukovich rely on state practice, and general principles of international law, which itself is practice widely accepted by states within their national legal systems. However, States do not have a common, consistent, widespread practice of according the rights to selfdetermination - at least not outside the decolonization framework. See M. Cherif Bassiouni, $A$ Functional Approach to "General Principles of International Law”, 11 MicH. J. INT'L L. 768, 768773 (1990) (discussing that General Principles are primarily reflected through national legal systems, and are understood to be "cardinal", "common"-although at times they might require further elaboration — or are "unperfected").

94. Cf. Jean-Pierre L. Fonteyne, The Customary International Law Doctrine of Humanitarian Intervention, 4 CAL. W. INT'L L. J. 203, 233 (1974) (citing Louis Hnekin in Biafra, Bengal and Beyond: International Responsibility and Genocidal Conflict, 66 Proc. Am. SoC'y INT'L L. 89, 9697 (1972) (discussing Lauterpacht's conclusion that the infrequency of an act should not be determinative of its existence, since states often do not participate where there are chances of “conflagrations")).

95. Brad R. Roth, Secessions, Coups and the International Rule of Law: Assessing the Decline of the Effective Control Doctrine, 11 MELB. J. INT'L L. 393, 440 (2010).

96. Orfeas Chasapis Tassinis \& Sarah Nouwen, Anticipating the Chagos Advisory Opinion: The Forgotten History of the UK's Invocation of the Right to Self-Determination for the Sudan in the 1940s, EUR. J. INT'L L. TALK (Feb. 19, 2019), https://www.ejiltalk.org/anticipating-the-chagosadvisory-opinion-the-forgotten-history-of-the-uks-invocation-of-the-right-to-self-determination-forthe-sudan-in-the-1940s/ [https://perma.cc/9JER-CEFV] (discussing the case of Britain which had invoked self-determination rights around the 1940s, while it was co-administering Sudan along with Egypt. The Britishers had staffed their own within the Sudanese government and had invoked the 
The presumption that self-determination is contingent on the resistance of the people itself fails to acknowledge the asymmetric division of powers between the state and its peoples. The ICJ in its Kosovo Advisory Opinion of 2010, showed exactly how political the process of external self-determination is. ${ }^{97}$ In answering the question of whether Kosovo's declaration of Independence was legal neither in the positive nor in the negative, ${ }^{98}$ the ICJ managed to influence the international community's perspective that eventually led to Kosovo's recognition. ${ }^{99}$ The ICJ held that the "scope of the principle of territorial integrity is confined to the sphere of relations between States." 100 At the same time, the Court held that the principle of non-use of force would, nevertheless, apply between the State and the secessionists. ${ }^{101}$ For Security Council Resolutions declaring the use of force as illegal and their bearing on the Kosovo situation, the ICJ clarified that the illegality did not relate to the unilateral declaration of independence; rather, in those cases, they were accompanied by the unlawful use of force or other "egregious violations of norms of general international law, in particular those of a peremptory nature." 102 The Court noticed that in the context of Kosovo, the Security Council has never taken a similar position. ${ }^{103}$ This is because the Kosovars never resorted to the use of military force; instead, they continued to respect the authority of the interim administration. ${ }^{104}$

But the Court failed to consider that in the course of legitimate secessionist struggles, States often resort to preventive wars. ${ }^{105}$ Legitimate secessionist

right and the principles of U.N. Charter before the UNSC to keep Egypt out).

97. See Accordance with International Law of the Unilateral Declaration of Independence in Respect of Kosovo, Advisory Opinion, 2010 I.C.J. 403, ๆๆ 82-23 (July 22) [hereinafter Unilateral Declaration of Independence in Respect of Kosovo]; Walter, supra note 71; G.A. Res. ES-10/14 (Dec. 12, 2003); G.A. Res. 63/3 (Oct. 8, 2008).

98. Unilateral Declaration of Independence in Respect of Kosovo, supra note 97. Although the question for "remedial secession" came up, the Court considered it to be, "not necessary" to delve into this question. The question referred to the Court by the General Assembly over whether Kosovo's Declaration of Independence was lawful, would have warranted such an opinion over remedial secession. It only observed, ambiguously, that the right to self-determination has evolved. Id.

99. Walter, supra note 71 , at 13,15 ("contributing defacto to the acceptance of the practical result"). In doing so, the Court linked the principle of territorial integrity to Article 2(4) of the UN Charter, the Helsinki Conference's Final Act and the 1970 Declarations.

100. Unilateral Declaration of Independence in Respect of Kosovo, supra note 97, 980.

101. Id. $\uparrow \uparrow$ 80-81. Despite noting that the principles on non-use of force (which are placed alongside the principle of territorial integrity) apply only to states, it notes that several declarations of independence (inevitably made by peoples and non-state actors), which were condemned by the Security Council, were treated on a case-by-case basis. Id. This implies, that the principles on nonuse of force would also apply to secessionists.

102. Id. ๆ 81 .

103. Id.

104. Walter, supra note 71, at 20.

105. Jack S. Levy, Declining Power and the Preventive Motivation for War, 40 WoRLD 
struggles are also the product of massive repressions, so the use of force is often in self-defense. ${ }^{106}$ Hence, if the legality of secessionist struggles is based on the non-use of force, such struggle is hardly expected to succeed. ${ }^{107}$

Crawford's conclusion that the examples of Bangladesh, Eritrea, or the Baltic States could not serve as examples of the existence of the right itself, does not appear to be correct, although the successful exercise of such right is usually contingent on external factors. ${ }^{108}$ Self-determination cannot be viewed as an isolated concept. In Professor Ved Nanda's work on the separation of Bangladesh from Pakistan, he laments the lack of precise guidelines in the context of unilateral non-colonial self-determination units. ${ }^{109}$ Professor Nanda's contribution to the literature involves placing self-determination at the confluence of territorial integrity and humanitarian interventions. ${ }^{110}$ Similarly, Milena Sterio, in her discussion on self-determination of the constituent units of Yugoslavia, argues that in such cases where there exists a legitimate right, the peoples would be "fully entitled to seek and receive external aid and third-party states and organizations would have no duty to refrain from providing support." 111 She further argues that the success of a secessionist struggle depends on external factors such as the support of the great powers and the administration of a territory by international organizations, as in the case of Kosovo. ${ }^{112}$ Ed Brown supports this idea by referring to the Responsibility to Protect (R2P) doctrine that concerns the duty of the "international community" to intervene in situations where states are either unable or unwilling to protect their citizens against massive violations of human rights. ${ }^{113}$ The duty could extend in certain situations

Politics 82-107 (1987).

106. Crawford, supra note 87; Noronha Dos SANTOS, supra note 24, at 16 (regarding how secessionist struggles acquire an "unbending character" once the parent State uses repression against the peoples and how it provides secessionists with a cause to justify their acts of terrorism).

107. Walter, supra note 71, at 19-21 (discussing how the Court erred in holding that the principle of territorial integrity only applies in interstate relations, while the principle of non-use of force applies even to non-state actors, or in this case secessionists, since the principle of non-use of force directly flows from territorial integrity).

108. See Fareed, supra note 86.

109. Nanda, supra note 76.

110. Id.

111. Milena Sterio, On the Right to External Self-Determination: 'Selfistans, 'Secession, and the Great Powers' Rule, 19 MinN. J. INT'L L. 137, 147 (2010).

112. STERIO, supra note 35, at 60-62.

113. Ed Brown, The United Nations, Self-Determination, State Failure and Secession, in THE UN Friend or Foe OF SELF-DEterminAtion 93-94 (Jakob R. Avgustin ed., 2020) (discussing how the responsibility to protect mechanism can be seen as complementing the remedial right to secede since a state which claims sovereignty also has a duty to protect). Brown believes that if this responsibility is acknowledged by the $\mathrm{UN}$, then the right to secede should also be. Hence, if the parent state fails to provide security and indulges in human rights violations, a sub-State group can secede. Note, the Responsibility to Protect here is framed in terms of the duties of the parent state 
to the carrying out of humanitarian interventions, which have been referred by Nanda and Sterio above, although only after the exhaustion of all peaceful means. ${ }^{114}$ The R2P doctrine was adopted in the International Commission on Intervention and State Sovereignty (the "ICISS")'s 2001 Report in the aftermath of the NATO bombing in 1999 of Yugoslavia over the ethnic cleansing in Kosovo.

The doctrine was a direct result of the finding that although the NATO bombing could have been illegal because it did not follow the enforcement procedure under the UN Charter, it was nevertheless legitimate. ${ }^{15}$ This doctrine has its own flaws. Thomas G. Weiss notes that the term, "international community" is vague and in the absence of a particular body lacks a policy effect. ${ }^{116}$ Also, the ICISS's Report makes it clear that whosoever intervenes must do so with the authorization of the UNSC. ${ }^{117}$

The ICJ's Advisory Opinion on the Wall also discussed the affirmative role to be played by the international community and the UN bodies in the context of the self-determination rights of the Palestinian peoples. The Opinion held that

but builds into the R2P mechanism that imagines the duty of international community because the community's role becomes legitimate only once the state fails in its responsibility. This external intervention might also be of assistance to secessionist groups, who might be the victims of persecution. George Nolte, External Intervention, in SECESSION: INTERNATIONAL LAW Perspectives 69-93 (Marcelo G. Kohen ed., 2006) (discussing that non-intervention is premised on UN Charter arts. 2 ๆ 1,4 , and 7 prohibit the use of force and favour territorial integrity. However, sovereignty is not absolute and with the growing framework of human rights, it is now understood that violations of human rights is a matter of international concern. Thus, the international community may accordingly intervene, although it is mostly the UN Security Council that takes such collective measures whereas unilateral use of force is still objected). See also Ralph Janik, The Responsibility to Protect as an Impetus for Secessionist Movements: On the Necessity to Re-Think Territorial Integrity, in GRENZEN IM VÖLKERRECHT 41, 54-62 (Matthias Kettemann ed., 2013) (discussing how secessionist struggles could be motivated by the Responsibility to Protect doctrine, creating a "moral hazard." Secessionists could actively use violence and provoke the state into repression to obtain external assistance).

114. G.A. Res. 60/1, ๆๆ 138-40 (Sept. 16, 2005).

115. Tom J. Farer, Humanitarian Intervention Before and After 9/11: Legality and Legitimacy, in Humanitarian Intervention Ethical, Legal, and Political Dilemmas 53, 67-68 (J.L. Holzgrefe \& Robert O. Keohane eds., 2003) (noting how Reisman talks of the lines between legality and legitimacy being blurred since even though the procedural requirements of enforcement actions under Chapter VII were not followed, i.e. the Security Council had not taken any steps, the substantive obligations had been met; the majority of the international community agreed that the intervention was just). This doctrine was reiterated in the 2005 World Summit and the UN HighLevel Panel on Threats, Challenges and Change where the discussion was over the shift from a "right to intervene" to a "responsibility to protect."

116. Thomas G Weiss, Researching Humanitarian Interventions: Some Lessons, 38 J. PEACE RSCH. 419, 423-24 (2001).

117. James Pattison, Humanitarian Intervention AND the Responsibility to Protect: Who SHOULd INTERVENE? 4 (2010). 
every State has a legal obligation to not recognize the illegal situation arising as a consequence of Israel's act of constructing a wall in occupied territories and to not render aid or assistance in maintaining the situation. ${ }^{118}$ Additionally, Member States are under an obligation to see any impediment to the rights of the Palestinian people in their exercise of the right of self-determination brought to an end. ${ }^{119}$ In the subsequent part of the judgment, the ICJ states that the United Nations, especially the General Assembly and the Security Council must consider the necessary action to be taken to end this situation as if to clarify that no state must act unilaterally. ${ }^{120}$

In the course of bringing such impediment to end, the international community must be wary of overreliance on the process of political negotiations. ${ }^{121}$ Even successful cases of self-determination through the consent of the parent State and over negotiations were preceded by some form of intervention. For instance, in Kosovo, the UN Mission and the Provincial Institutions of Self-Government were set up only following the NATO bombings and remained in the territory from 1999 to 2008 when the Kosovars declared independence. ${ }^{122}$ Similarly, the establishment of the International Force East Timor was also preceded by non-military coercive intervention, in the form of economic measures, by the international community. ${ }^{123}$ If Kashmir were any example, diplomatic talks have been stalled for years. Not only is a strong State likely to resist them, but in cases where the secessionist claims are legitimate, such negotiations often result in the balance of power shifting. ${ }^{124}$

118. Legal Consequences of the Construction of a Wall in the Occupied Palestinian Territory, Advisory Opinion, 2004 I.C.J. 136, \ 159 (July 9).

119. Id.

120. Id. $\uparrow 160$.

121. There is a general push for political settlements and truces over any coercive actions, without taking account of facts such as resoluteness of the sub-State group, legitimacy of the state, unwillingness of the government, past injustices and present repression, etc. See, e.g., Jane E. Stromseth, Self Determination, Secession and Humanitarian Intervention by the United Nations, 86 Proc. of the Ann. Meeting (AM. Soc'y of INT'L L.) 370-74 (1992) (emphasizing solutions such as investigation of disputes in the early stages of conflict and negotiated settlements, push by the Secretary General towards defusing a conflict through mediation, or peacekeeping operations where the parent state consents, and noting that enforcement actions that lie at the other end of the spectrum are hardly opted). Gyda M Sindre, From Secessionism to Regionalism: Intraorganizational Change and Ideological Moderation Within Armed Secessionist Struggles, 64 Pol. GeOGRAPHY 23-32 (2018) (the study begins with the assumption that the proper way to resolve secessionist claims is for the parent State to provide autonomy and enter into political settlements such as power-sharing, rather than for the international community to accord recognition, looking into aspects such as how moderate or alternative visions arise within the nonstate actors who formerly supported secession).

122. STERIO, supra note 35 , at 62 .

123. Farer, supra note 115 , at 57-58.

124. James D Fearon, Rationalist Explanations for War, 49 INT'L ORG. 379, 406 (1995). 
As for the response from the UNSC that has been vested with the powers to take enforcement actions under the UN Charter, Michael Reisman notes that there would be several instances where the Council could fail to act. ${ }^{125}$ Reisman believes that states should, in the alternative, resort to unilateral interventions. ${ }^{126}$ However, as observed in the past, unilateral interventions could be open to abuse. Therefore, in cases where the "great powers" frequently stall resolutions in the UNSC, the powers could pass on to the General Assembly. ${ }^{127}$ In this regard, special sessions of the General Assembly could be conducted to take up resolutions or the matter could be referred to the General Assembly by the Secretary General. ${ }^{128}$ The General Assembly could either make recommendations to the Member States on how to respond or they could refer questions to the ICJ for an advisory opinion, as was done in the ICJ's Wall Advisory Opinion or the Kosovo Opinion. ${ }^{129}$

After the Kosovo Advisory Opinion where the ICJ did not explicitly rule out the possibility of secession and refused to call the declaration of independence as unlawful, several political consequences followed. Serbia sought to present a Draft Resolution which stated that unilateral secessions were unacceptable - but in the lack of any illegality attached to the act - it did not find any support and was forced to withdraw it. An alternative resolution was adopted that allowed the European Union to intervene and facilitate cooperation between Kosovo and Serbia. ${ }^{130}$

From the discussion above, it is observable that self-determination rights cannot be effectively exercised in the absence of the international community's participation. While coming to a decision, the international bodies must remember to not simply adopt a traditionalist approach to sovereignty, as has been adopted in the case of Kashmir, since the same issue could have different dynamics. For instance, enforcement bodies such as the Security Council might tend to view an issue from a political lens and accordingly propose political resolutions, mediations, and settlements. Whereas, human rights treaty bodies

125. Cf. W. Michael Reisman, Unilateral Action and the Transformations of the World Constitutive Process: The Special Problem of Humanitarian Intervention, 11 EUR. J. INT'L L. 3, 1415 (2000) (noting in reference to the "constitutive process" that in certain cases, there might be an absence of consensus amongst the permanent members but a grave and urgent situation arising. The absence of consensus, according to Reisman, stems from how certain states maybe impelled to act based on their democratic experience, while some states were still in the process of transition or led by a dictatorship).

126. Id. at 7-8, 15 (2000).

127. Yasmine Nahlawi, Overcoming Russian and Chinese Vetoes on Syria through Uniting for Peace, 24 J. Conflict \& Security L. 111, 114-115 (2019). The Uniting for Peace (UforP) Mechanism was also invoked in the Wall Opinion, when the UNGA had convened the 10th emergency session after the UNSC had voted down the Draft Resolution twice. See id.

128. Id.

129. G.A. Res. ES-10/14 (Dec. 12, 2003); G.A. Res. 63/3 (Oct. 8, 2008).

130. Walter, supra note 71 , at 13,18 (noting how the Advisory Opinion led to the “international community's acquiescence with development"). 
would examine it from a human rights violations lens and propose solutions such as investigations by independent experts. International adjudicatory mechanisms could examine it from the lens of responsibility or legality of the sub-State group's claims and subsequent actions. Acknowledging this would have a direct bearing on how self-determination instances are tackled.

\section{CONCLUSION}

Although the right to self-determination has been explicitly mentioned under the UN Charter and other treaties, the exercise of this right lacks a normative framework. This lack of norms allows states to unilaterally decide whether or not the peoples with legitimate claims should be granted independence. Hence, even legitimate struggles with similar facts of repression may not be successful, especially when the parent state in question is not a "rogue" or a weak state. While States are more amenable to grant limited sovereignty or autonomy to peoples, external self-determination claims involve territorial questions and so are met with greater resistance. This is visible through the fact that prior to an intervention in favor of such peoples, States have avoided reasoning it as one motivated by the self-determination rights of the people, in an attempt to avoid being ascribed with such state practice. Thus, to be successful, the peoples must not merely have been restricted from participation in the political process of the parent State and faced with massive violations of human rights, but also be assisted through interventions from the international community. As in the case of Kashmir, each further act of right violation must be seen as a revival of the peoples' claims that cannot be addressed merely through political negotiations. 